\title{
PROBLEMS OF HILL COUNTRY IMPROVEMENT
}

\author{
By H. V.S. LARSEN, Uruti.
}

The three properties with which I am going to deal belong to the marginal land group and were taken over about 1906-10, the main incentive being free rent for 4 years and the low unimproved value, namely $12 \mathrm{~s}$. $6 \mathrm{~d}$. to $25 \mathrm{~s}$. per acre. The tenure was L.I.P. or O.R.P. and the rent about 4 per cent. of the unimproved value.

After taking over, the problems were many: bad burns, tutu, second growth of scrub, bracken fern, carpet fern, poor 'roading access, etc. Many failures resulted and the settlers not broken were badly bent. However, the few who remained gained experience and over the years found ways and means of overcoming many of the problems confronting them. In summing up, we must remember that these settlers were, in the main, unfinancial and unable to tackle jobs on a big scale. They were inexperienced in this type of country and it is only during the last 20 years that sufficient knowledge has been gained to act as a stimulant to further endeavour.

In 1919 I bought a farm of 1635 acres ; 420 of these had been felled from native bush and were reverting to bracken fern and scrub, 86 had been felled but not burnt, and the balance of 1215 acres was standing bush. The whole farm consisted of strong blue papa, lying well to the sun, but was only carrying 630 ewes and a handful of cattle. The farm was purchased under the returned soldier scheme, whereby $£ 750$ was advanced for stock, $\$ 500$ for further improvements, and $\$ 1800$ for the farm, which was O.R.P. at 12 s. $6 \mathrm{~d}$. per acre. The only access was, and still is, by 6 miles of bridle track.

In 1928 I bought another farm of 558 acres freehold, 10 miles nearer civilisation and with a clay road access. There were about 400 acres in grass and scrub with the balance in bush, the carrying capacity being 230 sheep and 50 cattle.

In 1942 I purchased another farm of 1473 acres 
with approximately $1000^{\prime}$ acres in grass, the rest in bush. The carrying capacity was 1000 sheep and some cattle. The area then totalled 3666 acres, half of this bush ; the total carrying capacity was 1860 sheep, and about 100 cattle.

To summarise the position :-

\begin{tabular}{|c|c|c|c|c|c|c|c|}
\hline & & $\begin{array}{l}\text { Area } \\
\text { acres }\end{array}$ & $\underset{\text { grass }}{\text { Area in }}$ & $\begin{array}{l}\text { Area in } \\
\text { bush felled } \\
\text { but not }\end{array}$ & $\begin{array}{l}\text { Area in } \\
\text { standing } \\
\text { bush }\end{array}$ & Sheed & Cattle \\
\hline \multicolumn{8}{|l|}{ Kirtons } \\
\hline 1918 & - & 1635 & 420 & 86 & 1215 & 630 & 20 \\
\hline \multirow[t]{2}{*}{1951} & . & 1635 & 1200 & - - & 435 & 2000 & 470 \\
\hline & & & & & & $\begin{array}{c}(1400 \text { hog- } \\
\text { gets } 600 \\
\text { ewes })\end{array}$ & $\begin{array}{c}\text { (230 grown } \\
\text { cattle } 38 \\
1 \frac{1}{2} y r s . \\
200 \text { ylgs.) }\end{array}$ \\
\hline \multicolumn{8}{|c|}{ Homestead } \\
\hline 192216 & - & อิ & 498 & & 108 & 980 & $\begin{array}{l}100 \\
\text { all cows }\end{array}$ \\
\hline \multicolumn{8}{|l|}{ Putts } \\
\hline 1942 & - & 1473 & 1000 & & 473 & 1000 & \\
\hline 1951 & & 1473 & 1100 & & 373 & 2130 & $4 \%$ \\
\hline Total & & & & & & & $(330$ cows $)$ \\
\hline 1951 & - & 3666 & 2 & 8 & 908 & 5090 & 970 \\
\hline
\end{tabular}

In 1951 there were no mortgages on the properties and I had a $£ 2000$ overdraft; $\$ 5250$ was retained under the "wool freeze."

The contour of this country varies considerably ; the largest proportion is very hilly, a smaller proportion is undulating, and 500 acres flat, mainly terrace country. This last is fairly fertile, good swede country, and responds very well to topdressing and grassing out.

Frosts are very severe, averaging two or more a week from May to September. The rainfall is $75 \mathrm{in}$. per annum'and the altitude 500 to $1200 \mathrm{ft}$.

I have cut all second growth at least once. Since then I have cut all manuka at least once every 5 years, making sure that it has not been allowed to seed out. The results from this method have been good, although' manuka still persists on sandstone and papa slips when grass will not grow successfully.

On the terrace country, a poor subsoil of red clay loam is covered by 3 to $6 \mathrm{in}$. of black volcanic soil having a slight deficiency of potash, and a marked deficiency of phosphate and lime. This land, however, grows excellent swedes and chou moellier and after being grassed out and topdressed will winter 5 ewes to the 
acre. The valleys are in the main papa with here and there a mixture of: sandstone. These sandstone areas are inclined to run to danthonia and browntop, whereas the strong softer blue papa, with reasonable grazing, maintains English grasses and clovers fairly well. There are also a number of rich papa basins in which rushes grow prolifically but with Lotus major much in evidence on which a large number of stock is carried.

The original forest consisted in the main of tawa, rimu, pukatea, mahoe, rata, supplejacks, kie kie; and soft woods, with, on the poorer type of country some tawhera, hinau, honeysuckle, konini, wineberry, and miro.

After felling and burning the two worst menaces were wineberry in the gullies where the burn was light, and soft fern on the dry spurs where peat persisted. The peat consisted of partly rotted leaves and twigs which would dry out in summer,' leaving the grass to die and the fern to flourish. To overcome this the peat had either to be burnt off in a drought or consolidated by tramping with stock, which was possible only after about 10 years when the protective timber had rotted.

My experience of this country has been that it goes through three stages, the first being the 2 years immediately after a burn, when the growth of grass is wonderful ; the second and most critical when the pasture tends to revert to scrub and fern; and last, the improvement of the sward by topdressing, etc. During the second stage, to retain the pasture, you must consolidate with cattle. Here you are up against the timber problem. The cattle I prefer for the hill country are Polled Angus, because they are hardy, climb well, and are a popular fattening breed. Of these .I run 1 beast to 5 or 6 sheep. I cannot further increase this ratio on account of ragwort, which even now would spread if I reduced the number of sheep. This consolidation cannot be done with sheep, because plants if too closely fed off have not sufficient herbage left to build up food supply from the air, which is essential, for vigorous plant growth. Thin pasture results and the inroad of danthonia, browntop, and weeds begins.

All fences I erect are of 8 wires, with a gap of only 8 in. between the two top wires, thus preventing cattle straining the fence by poking their heads through; and $5 \mathrm{in}$. between the three bottom wires to prevent sheep from -bailing themselves up. Posts are spaced $5 \frac{1}{2}$ to the chain and battens 28 to the chain. 
The height of the fence is $3 \mathrm{ft} .10 \mathrm{in}$. I endeavour to fence off all shady faces into paddocks of their own. On the three farms I have 35 main paddocks, an average of 80 acres. However, the size of the paddock does not matter provided you have sufficient stock to concentrate in it. Rank grass must be eaten off between lamb weaning in January and tupping in March. This means increasing the normal carrying capacity to about six times for short periods of 4 or 5 days.

Since 1935-36 costs have increased about 300 per cent. I have always used my own labour to make improvements, with a few exceptions, such as bushfelling and bulldozing. My wages bill for this last year was approximately $£ 1$ per acre. I require a fair amount of labour for seasonal, jobs such as shearing, docking, crutching, dipping, etc. These take up about 4 or 5 months of the year and so we spend the rest of the year in scrubcutting, ploughing, fencing, and grass seed sowing. The calendar for the year is briefly thus:

January-February : Scrubcutting, fairs, dipping.

March-April : Burning, seed sowing, holidays.

May : Crutching.

June-July: Feeding off swedes (one man only) ; others fencing.

August-September : Lambing and fencing.

October : Docking.

November : Shearing.

December : Ploughing and cropping. year.

Scattered scrub is cut at odd times during the

When ploughing for swedes I allow ten acres for every 1000 sheep plus a little extra for calves. I begin feeding off on 1st June, taking them off every night. About 20th July I turn them out on their lambing paddocks. This spells all your country from sheep during the two worst winter months. The cattle do well, as they have all the clearing to themselves. They are then in good heart to stand up to the severe months of August and September.' If you feed your crop off later, your pasture gets too bare and takes too long to recover.

You must flush your ewes with good grass during tupping. When tupping is over, crutch them, and put them on the swedes. Your pastureswill thus be green all the winter. I have 30 or 40 acres of swedes every year which I should hate to be without. I must winter enough stock to maintain the pasture in the summer.

Owing to Scotch thistle I have 'always sown down 
my ploughed paddocks in September or October. I mix 401b. of seed in the following proportion :

Ryegrass 25lb., cocksfoot 8lb., crested dogstail $4 \mathrm{lb}$., and white clover 3lb., using only the best seed . available.

The little topdressing I have done has been on ploughed and sown-down pastures using mainly super; phosphate. However, this year 100 tons of superphosphate plus 15 per cent. potash were sown by air and results are expected.

Our worst weed is carpet fern, which covers about 20 per cent. of our hills. Stock will not eat it and after it is burnt off usually there is a ring of unburnt fern left on the windward side. This keeps on growing, gradually spreading back over the area that was burnt. It will not come in where there is a good sole of grass, but like hutiwai, danthonia, and browntop it will thrive best when hard grazed with sheep. I am hoping that by topdressing over a period of years the carrying capacity will be so increased that the cattle will tramp it out. This fern being surface rooted will not stand tramping.

I think I owe a great deal of my success to goats. Over the years very many acres of fallen scrub, which had not burnt, were cleaned up by goats. The sprouted stumps were so persistently trimmed that they died. The goats would break tracks through the rotting scrub, to be later followed by cattle and sheep. The poisonous tutu was the first to be eaten by goats, thus enabling cattle to be used, which was impossible before.

Now I have given you the history of this land and a few observations would not be amiss.

A farm must run 800 ewes and replacements to be economic to a man with a family. It takes 500 ewes to pay ordinary farm expenses and keep, while the balance is wanted for repayment and improvements on the farm.

Leave all the gorgy country alone.

To winter your stock you must have 10 per cent. of your farm ploughable. Sow only English grasses and clovers.

It is easier to borrow money than to pay it off. You can stand up to a cold winter better with your clothes on than off.

Never yard your ewes overnight with the rams at tupping time if you want good percentages. The rams won't stand the strain. Try a 24 hour fast yourself and see how fit you are. 
Remember that a temporary job is a certain waste of time.

A horse not used is costing you the profits from 8 sheep.

A broken gate or a hole in the fence is leaving. you . with one paddock less.

If you have manuka, you must cut one-quarter of the area each year, or it will win. Never burn standing manuka if in seed. It pays to burn cut manuka and get good grasses established. When cutting don't leave any branches on the stump uncut, as the seed on these will germinate after burning.

It takes 8 years of close grazing with cattle to kill bracken fern thoroughly. You cannot master bracken fern by rotational grazing. You must keep your cattle on the whole area from September till the end of March.

Don't expect too much of your cattle. They cannot crush fern and rear you a big percentage of calves every year. They just can't do it!

In 1920-30 it took the profits or rather returns

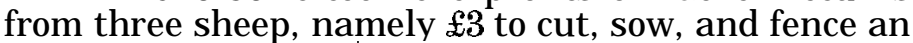
acre of scrub. In 1950-51 it takes the returns from two and a half sheep, i.e., $\$ 14$.

In conclusion, I believe that if a long-term agreement is reached for the sale of our meat and wool, the result will mean a large but gradual increase in the production from our marginal lands. The opportunity is here, but no one can afford to pay today's costs with yesterday's prices; but if we know that tomorrow's returns will be as good as today's, or nearly so, the incentive will be there. If costs and prices are stabilised this marginal land will soon come back to production. Give the young men of today that incentive and they will do the rest. 